\title{
NEW OSTRACODE SPECIES FROM THE UPPER CRETACEOUS OF THE SANTOS BASIN, BRAZIL
}

\author{
ENELISE KATIA PIOVESAN, CRISTIANINI TRESCA STRO BERGUE \& GERSON FAUTH \\ L aboratório de M icropal eontologia, UNISIN OS, Av. Unisinos, 950, 93022-000, São L eopoldo, RS. \\ kpiovesan@unisinos.br, ctbergue@gmail.com,gersonf@unisinos.br
}

\begin{abstract}
Two new species of Cretaceous ostracodes from the Santos Basin are proposed here: Afrocytheridea? cretacea sp. nov. and Pelecocythere dinglei sp. nov. The first one possibly constitutes the youngest record of Afrocytheridea, a typical Jurassic genus, while the latter the eldest of Pelecocythere. Both genera are typical elements of Gondwanide ostracode faunas and are recorded for the first time in B razil. The pal eoecologic and pal eogeographic aspects of these two new species are discussed based on other published occurrences of Pelecocythere and Afrocytheridea.
\end{abstract}

Key words: Afrocytheridea, P elecocythere, ostracodes, taxonomy, Santos B asin, B razil.

RESUM 0 - Duas novas espécies de ostracodes do Cretáceo da bacia de Santos são propostas: Afrocytheridea? cretacea sp. nov. e P elecocythere dinglei sp. nov. A primeira é possivel mente o registro mais recente de Afrocytheridea, um gênero típico do J urássico, enquanto a última constitui o registro mais antigo de Pelecocythere. Estes gêneros são elementos típicos da fauna de ostracodes do Gondwana, e são registrados pela primeira vez no B rasil. 0 significado pal eoecológico e pal eogeográfico destas espécies é discutido com base em outros registros de P elecocythere e Afrocytheridea previamente publicados.

Palavras-chave: Afrocytheridea, Pelecocythere, ostracodes, taxonomia, bacia de Santos, B rasil.

INTRODUCTION

The U pper Cretaceous deposits from B razilian marginal basins are very rich in both marine and coastal (=inner shelf, with variable influence of freshwater discharge) ostracode faunas. Despite being relatively well studied in the northeastern region (e.g. Delicio et al., 2000; Viviers et al., 2000; Fauth et al., 2005; Piovesan et al., 2009), studies in the south/southeastern basins are still very scarce. In the Senonian of the Santos Basin, the marine ostracode faunas are dominated by the Brachycythere-BairdoppilataCytherella-Majungaella association, while in the coastal environment the faunas are composed mainly of Fossocytheridea and Afrocytheridea.

The main purpose of this article is to describe two new species typical from those environments: Afrocytheridea? cretacea sp. nov. (coastal) and Pelecocythere dinglei sp. nov. (marine). Although these genera are fairly well known in other Gondwanide faunas, there is no published record of them in B razilian basins. Afrocytheridea is a shallow marine inhabitant whose type species has been described in the Middle Callovian of Tanzania as a cytherideid and later assigned to the family Progonocytheridae by Whatley \& Ballent (2004). The cytherurid Pelecocythere, on the other hand, has been recorded in both bathyal and abyssal depths, in the Cenozoic with occasional occurrences in the Cretaceous.

\section{STUDY AREA}

The Santos Basin is located in the southeast part of the B razilian continental margin, between latitudes $23^{\circ} \mathrm{S}$ and $28^{\circ} \mathrm{S}$ (Figure 1). The evolution of the basin is related to the break-up of Gondwana. The firstmarineformations were deposited during the early A lbian as a result of South A tlantic opening. The sedimentary record of this basin ranges from the Lower Cretaceous (Hauterivian) to the Quaternary. The Cretaceous marine section is composed of the A riri, Florianópolis, Guarujá, I tanhaém, Santos, Juréia and Itajaí-A çu Formations which are the record of global and local sea-level changes and tectonic events (M oreira et al., 2007). During the Senonian, the sedimentation processes were strongly influenced by the Serra do $\mathrm{M}$ ar uplift (at 90-80 $\mathrm{M}$ a) which prompted a coarse siliciclastic progradational trend (M odica\& B rush, 2004). Theinterval studied in the present work corresponds to the sandstones and shales of the J uréia Formation, deposited in continental to shallow shelf pal eoenvironments (M oreira et al., 2007).

\section{MATERIAL AND METHODS}

The 234 cutting samples studied are from the well SA N 04, cored by Petróleo B rasileiro S.A. (Petrobras). This well is $4,905 \mathrm{~m}$ in length and was sampled every nine meters. The samples were prepared according to the usual techniques for calcareous microfossils, involving disaggregation in hydrogen peroxide under heating, fractionating using three 


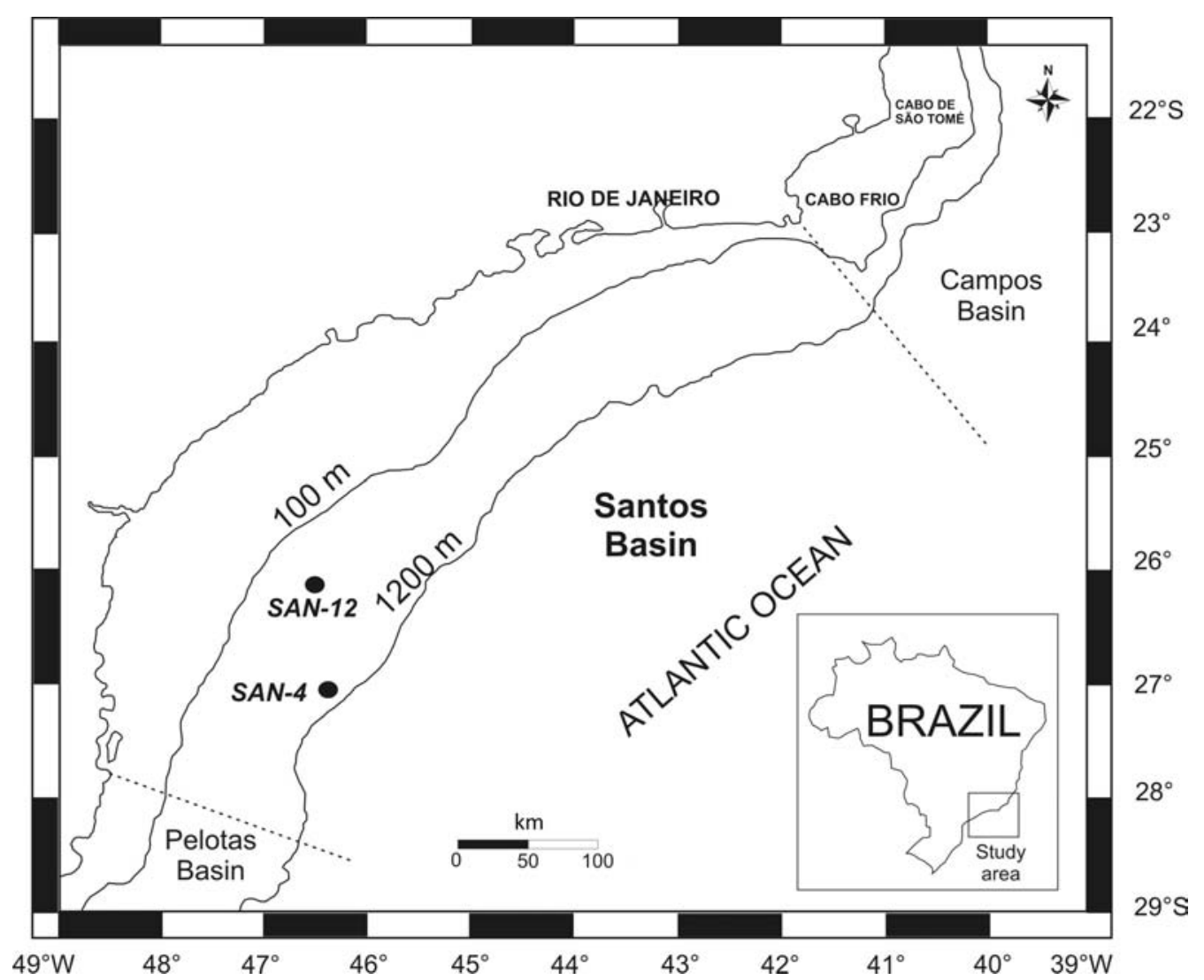

Figure 1. Location map of the Santos Basin, with the position of the wells studied (modified from Bergue \& Coimbra, 2008).

\section{CRETACEOUS DISTRIBUTION OF AFROCYTHERIDEA AND PELECOCYTHERE}

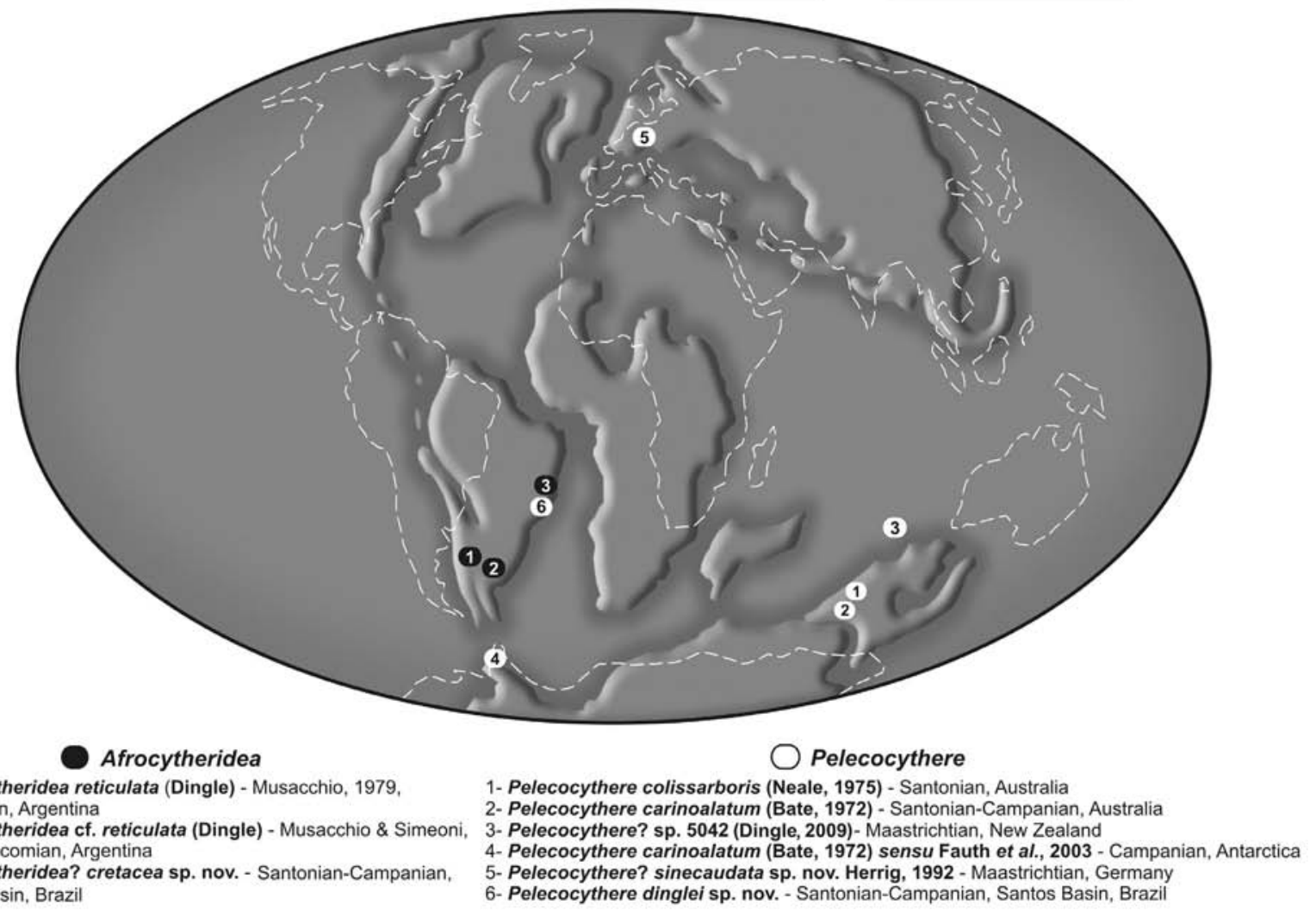

Figure 2. Cretaceous occurrences of the genera Afrocytheridea and Pelecocythere. Paleogeographic reconstruction from the Upper Cretaceous. Dashed lines indicate the actual position of the continents (modified from Scotese, 2009). 
meshes $(0.250,0.180$ and $0.062 \mathrm{~mm})$ and drying at $60^{\circ} \mathrm{C}$. A II the specimens from the three fractions were picked. Three specimens from another well situated nearby (SA N-12, sample $3,110 \mathrm{~m}$ ) were used as complementary material for the description of the species Afrocytheridea? cretacea sp. nov. The type specimens were cleaned in ultrasound baths for a few minutes before being imaged by SEM .

The type material is hold at the M useu de Paleontologia da U niversidade do Vale do Rio dos Sinos under the curator numbers ULVG-7342 to ULVG-7351. The suprageneric taxonomy adopted in this work follows Liebau (2005). M orphological abbreviations. C , carapace; $\mathbf{R V}$, right valve; LV, left valve; I, length; $\mathbf{h}$, height; $\mathbf{w}$, width.

\section{SY STEMATIC DESCRIPTIONS}

\author{
Order PODOCOPIDA M üller, 1894 \\ Suborder CY THEROCOPINA Gründel 1967 \\ Superfamily CY THERIDEOIDEA Liebau, 2005 \\ Family PR OGON OCY THERIDA E Sylvester-B radley, 1948 \\ Genus Afrocytheridea B ate, 1975
}

Type species. Afrocytheridea laevigata Bate, 1975.

Afrocytheridea? cretacea sp. nov.

(Figures 3A-G; Table 1)

\begin{abstract}
E tymology. In reference to the age of the species.
Stage. Santonian-Campanian.

M aterial. 1,055 carapaces.
\end{abstract}

Diagnosis. Carapace subrectangular, slightly depressed at anterior and posterior margins, rounded and posteriorly inflated, reticulated and with ribs in the ventro-lateral area. A ntero-dorsal sulcus oblique and short.

Description. Carapace subrectangular in lateral view. LV overlapping the RV except in the ventral region. M aximum height at the anterior cardinal angle; greatest width immediately after the median region. Dorsal margin almost straight in the RV and slightly projected upward in the posterior cardinal angle of $\mathrm{LV}$; ventral margin not seen due to the ventro-lateral inflation of the carapace. A nterior margin asymmetrically rounded, depressed, with a narrow sulcus and a rib along its length. This depressed area forms a projected rim easily noticeable in dorsal view. Posterior margin symmetrically rounded, projected upward, slightly acuminate at mid-height in the RV, and more angulate in the LV valve due to the swollen posterior cardinal angle. In dorsal view, the posterior margin has the same pattern as the anterior one. Ventral surface of carapace depressed in the middle and with longitudinal ribs. Surface reticulated, with conspicuous ventro-lateral ribs running from the antero-ventral to postero-dorsal area. Close to the posterior cardinal angle a feeble rib originates and runs al ong the dorsal margin becoming thicker and bifurcating at the anterior cardinal angle, forming an antero-dorsal sulcus. Sexual dimorphism pronounced: males longer and lower than females.

Stratigraphic distribution. Southeast Brazil: SantonianCampanian.

Occurrence. Well SA N-04: 2,879 m-4,473 m. Well SA N-12: 3,110 m.

Remarks. Afrocytheridea? cretacea sp. nov. is shorter and has the antero-dorsal furrow shallower than A. laevigata B ate, 1975. It is, moreover, smaller than A. faveolata, differing from both Bate's species by the strong reticulation and ventrolateral ribs concentrically distributed. Compared to $A$. reticulata Dingle (in: Dingle \& K linger, 1972), the length/ width ratio of the species described here is smaller, the posterior region more rounded and the dorsal margin less oblique. The precise generic position of this species is questionable. In spite of being morphologically and ecologically similar to Perissocytheridea Stephenson, 1938, it lacks the two welldeveloped antero-dorsal sulci and the inflation at the posterior third of the carapace, found in typical representatives of the genus (see Pinto \& Ornellas, 1970; Uliana \& M usacchio, 1978; A ndreau \& Ettachfini, 1994; Nicolaidis \& Coimbra, 2008). Although the internal features were not taken into account in the present description, the genus Afrocytheridea seems to be the most appropriate option to accommodate this species.

Family CY THERURIDAE M üller, 1894
Genus Pelecocythere A thersuch, 1979

Type species. Pelecocythere sylvesterbradleyi A thersuch, 1979.

Pelecocythere dinglei sp. nov. (Figures 3H-0; Table2)

E tymology. In honor of Richard Dingle for his contribution to Gondwanide ostracode research.

Stage. Santonian-Campanian.

M aterial. 13 carapaces.

Diagnosis. Carapace robust, strongly ornamented, with pronounced antero-dorsal sulcus. Alae poorly developed.

Description. Carapace large. Dorsal margin straight; ventral margin hidden by the outline. Ventral surface flattened, bordered by both a carinate alae and a ventro-lateral ridge.

Table 1. Type material of Afrocytheridea? cretacea sp. nov.

\begin{tabular}{cccccc} 
& & & \multicolumn{3}{c}{ Dimensions (mm) } \\
\cline { 3 - 6 } Type material & Collection number & Sample & lenght & height & width \\
\hline Female C (holotypus) & ULVG-7342 & SAN-04 3897 m & 0.46 & 0.26 & 0.35 \\
Female C & ULVG-7343 & SAN-04 3924 m & 0.46 & 0.28 & 0.33 \\
Female C & ULVG-7344 & SAN-04 3888 m & 0.50 & 0.29 & 0.33 \\
Female C & ULVG-7345 & SAN-12 3110 m & 0.43 & 0.25 & 0.26 \\
Male C & ULVG-7346 & SAN-12 3110 m & 0.60 & 0.29 & 0.34 \\
Male C & ULVG-7347 & SAN-12 3110 m & 0.55 & 0.25 & 0.29 \\
\hline
\end{tabular}




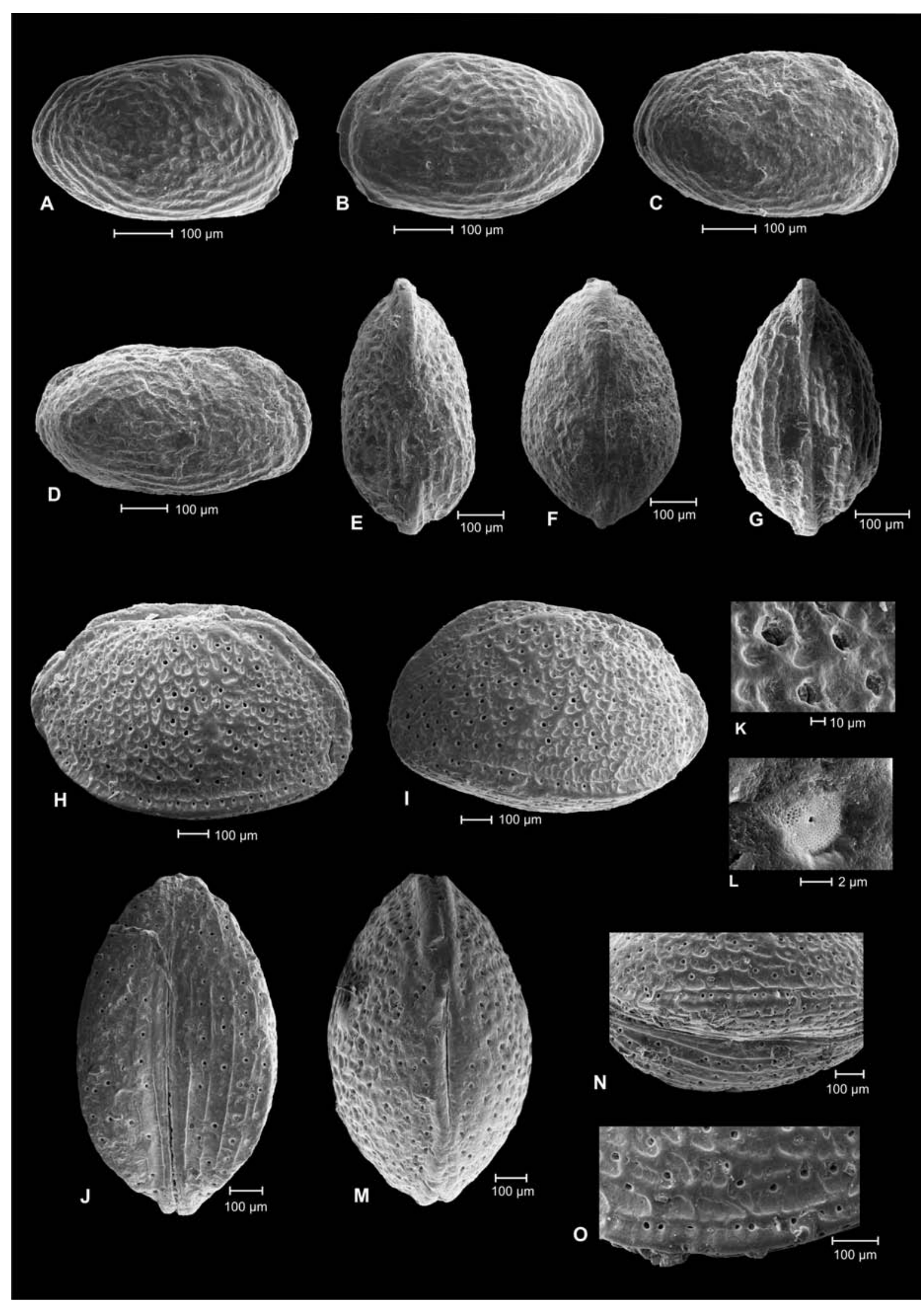

Figure 3. A-G, Afrocytheridea? cretacea sp. nov.: A,B, holotype, ULVG-7342, female C, lateral view, 3,897 m; A= RV; B= LV; C, paratype, ULVG-7343, female C, RV, 3,924 m; D, paratype, ULVG-7346, male C, RV, 3,110 m; E, paratype, ULVG-7347, male C, dorsal view, 3,110 m; F, paratype, ULVG-7344, female C, dorsal view, 3,888 m; G, paratype, ULVG-7345, female C, ventral view, 3,110 m. H-O, Pelecocythere dinglei sp. nov.: H-L, holotype, ULVG-7348, C, $3339 \mathrm{~m}, \mathrm{H}=\mathrm{RV}$; I= LV; J, ventral view; K, normal pore canals; L, detail of the sieve pore canals; M-O, paratype, ULVG-7349, $3303 \mathrm{~m} ; \mathbf{M}=\mathrm{C}$, dorsal view; $\mathbf{N}=$ carinate alae, with pore canals; $\mathbf{O}=$ detail of ornamentation. 
Table 2. Type material of Pelecocythere dinglei sp. nov.

\begin{tabular}{cccccc} 
& & & \multicolumn{3}{c}{ Dimensions $(\mathrm{mm})$} \\
\cline { 4 - 6 } Type material & Collection number & Sample & lenght & height & width \\
\hline C (holotypus) & ULVG-7348 & SAN-043339m & 1.05 & 0.62 & 0.67 \\
C & ULVG-7349 & SAN-043303 m & 1.04 & 0.59 & 0.64 \\
C & ULVG-7350 & SAN-04 4140 m & 1 & 0.58 & 0.59 \\
C & ULVG-7351 & SAN-043357 m & 1.05 & 0.54 & 0.58 \\
\hline
\end{tabular}

$M$ aximum height and maximum width in the middle of the carapace. A nterior margin depressed, rounded and oblique in the upper part; posterior end oblique at the upper part, with a small caudal process. Outline ellipsoidal in dorsal view. Ventral surface of carapace ornamented with eight longitudinal ribs, four in each valve. $L$ ateral surface reticulated, forming irregular fossae. Antero-dorsal region with pronounced sulcus running up to the antero-median portion of carapace. L eft valve overlapping the right one in the postero- and antero-dorsal margins. N ormal sieve-type pore canals, large and widely distributed over the lateral surface, but aligned al ong the carinate alae and the ventral surface.

Occurrence. Well SA N-04: 2,862 m-4,140 m.

Remarks. Pelecocythere dinglei $\mathrm{sp}$. nov. differs from $\mathrm{P}$. carinoalatum (Bate, 1972) from the Santonian-Campanian from $A$ ustralia, by the strong reticulation and the absence of the three parallel ridges in the alae. It differs from $P$. collisarboris (N eale, 1975) from Santonian from A ustralia, by the absence of the antero-ventral spination in the right valve. Furthermore, Pelecocythere dinglei sp. nov. is larger and more robust than the above mentioned species.

\section{DISCUSSION AND CONCLUSIONS}

The distribution of ostracode species during the Upper C retaceous in the Santos B asin was strongly influenced by sea level changes, which probably caused the faunal change observed in the well SAN-04. Based on the analysis of the ostracode fauna along the well, it is possible to propose the transition from a coastal (bottom) to a marine (top) environment.

In the samples from the lower part, predominate F ossocytheridea spp. and Afrocytheridea? cretacea sp. nov., which are the most abundant species in the well and which compose an association characteristic of mixohaline waters. Towards the top, the fauna indicates the establishment of fairly marine conditions, as indicated by the occurrence of Bairdoppilata, Brachycythere, Cytherella, M ajungaella and Paracypris.

Afrocytheridea is an extinct genus typical of the Jurassic/ Neocomian strata, and its presence in the Senonian of the Santos Basin represents the enlargement of its temporal distribution. Such pattern of evolution is, in some aspects, similar to that of Majungaella Grékoff, another Jurassic progonocytherid, which became more disperse and less diverse al ong the $C$ retaceous and Pal eogene (W hatley et al. 2005). Besides the species described here, only Afrocytheridea cf. reticulata (Dingle, 1972) has been recorded in the A merican continent (M usacchio, 1979, 1981; M usacchio \& Simeoni, 2008). This species was originally described in the genus Progonocythere and tentatively accommodated in Afrocytheridea by Whatley \& Ballent (1996,
2004). This A rgentinian species occurs associated with platycopids and cytheroids, with a very high ostracode/ foraminiferal ratio (only one species of Lagenina). The environment of deposition corresponds to restricted marginal marine conditions with warm waters and changing sal inity (Sara B allent, pers. comm., 2010). Similarly, its high abundance and association with F ossocytheridea in the Santos Basin indicate a coastal environment. It is possible that A frocytheridea might have had an ecological behavior similar to the Cenozoic species of P erisssocytheridea which can live in both transitional and internal platform environments.

The genus P elecocythere was described in abyssal depths of the North A tlantic and later recorded in many deep sea localities elsewhere. Despite the similarity to other cytherurids, such as Cytheropteron and Eocytheropteron, it differs from them by the presence of subdivided adductor muscle scars, sieve-type pore canals in the alae and longitudinal ribs along the ventral surface.

The more the study of deep sea ostracodes developed, the older the records of Pelecocythere became. Whatley $\&$ Coles (1987) recorded $P$. foramena for the M iocene of the North A tlantic, and Guernet \& Fourcade (1988) referred to P elecocythere trinidadensis (B old, 1960) in the Oligocene of B lake Plateau (O DP site 628A, Southeast A tlantic). Guernet $\&$ Danelian (2006) reported an older record of Pelecocythere cf. trinidadensis B old, 1960 in the Demerara rise (off Surinam) in the Eocene and, possibly, M aastrichtian. Although the poor preservation of the latter does not allow a conclusive statement about their generic position, there are other records which support more convincingly the C retaceous occurrence of Pelecocythere. Pelecocythere? sinecaudata H errig, 1992, described in the M aastrichtian of Germany, shows morphologic characteristics consistent with the generic diagnosis, such as the outline and the existence of pore canals along the alae. Dingle (2009) sustains that besides the species recorded in Waipara ( $\mathrm{N}$ ew Zeal and), the A ustralian species $P$ elecocythere carinoalatum and P. collisarboris are possibly other Cretaceous representatives.

Dingle (2009) suggests that during the Cretaceous, Pelecocythere was a shallow water genus, migrating during the Cenozoic to deeper or cold shallow water environments in a retrothermal adaptation. Some taxa that original ly lived in shallow water colonized deeper environments becoming widespread in both, such as Argilloecia Sars, Bythocypris Brady, Bairdoppilata Coryell, Samples \& Jennings and Cytherella J ones. Others, following the same pattern of adaptation, originated psychrospheric taxa living predominantly (e.g. Bradleya H ornibrook) or exclusively (e.g. Agrenocythere Benson, O blitacythereis Benson) there (Benson \& Sylvester-B radley, 1971). This process explains the ecologic separation of marine ostracodes, which began 
in the $U$ pper C retaceous and resulted in the distinct Cenozoic thermospheric and psychrospheric ostracode faunas.

$B$ ased on the published occurrences of Afrocytheridea and Pelecocythere in the Cretaceous (Figure 2), it can be assumed that, except for the record of Pelecocythere? sinecaudata ( $M$ aastrichtian, Germany), these genera were typical el ements of the Gondwanide fauna.

\section{ACKNOWLEDGMENTS}

The authors would like to thank Petrobras (Petróleo B rasileiro S.A.) for the samples used in this study, M .C. Viviers (Petrobras-Cenpes/DIVEX) for her important suggestions and R. M artins (Petrobras) for the SEM images. We also thank the staff of the Laboratório de Micropaleontologia of UNISINOS (Universidade do Vale do R io dos Sinos) for the support during the preparation of the work. Sara B allent and $B$. Andreau are thanked for the revision and constructive criticism of this manuscript.

\section{REFERENCES}

A ndreu, B. \& Ettachfini, E.M . 1994. Nouvelles espèces d' ostracodes du Cénomanien du Bassin d'Essouira (M aroc), implications paléoécologiques. Revue de Micropaléontologie, 37:3-29.

A thersuch, J. 1979. On P elecocythere sylvesterbradleyi A thersuch gen. et sp. nov. Stereo-Atlas of Ostracod Shells, 6(3):13-20.

Bate, R.H. 1972. Upper Cretaceous Ostracoda from the Carnarvon Basin, WesternA ustralia. Special Papers in Palaeontology, 10:1-85.

Bate, R.H., 1975. Ostracods from Callovian to Tithonian sediments of Tanzania, EastA frica. Bulletin of the British M useum Natural $\mathrm{H}$ istory, 26:161-223.

Benson, R.H. \& Sylvester-B radley, P. 1971. Deep-sea ostracodes and the transformation of ocean to seain the Tethys. Bulletin du Centre de recherches de $\mathrm{P}$ au, 5:63-91.

Bergue, C.T. \& Coimbra, J.C. 2008. Late Pleistocene and Holocene bathyal ostracodes from the Santos Basin, southeastern B razil. Palaeontographica, Abtleilung A, 285:101-144.

B old, W.A . van den. 1960. E ocene and Oligocene Ostracoda of Trinidad. Micropaleontology, 6(2):145-196.

Delicio, M .P.; Coimbra, J.C.\& Carreño,A .L . 2000. Cretaceous marine Ostracoda from the Potiguar basin, Northeastern Brazil. Neues Jahrbuch für Geologie und Paläontologie, Abhandlungen, 215(3):321-345.

Dingle, R.V.\& K linger, M . 1972. The stratigraphy and ostracod fauna of the Upper Jurassic sediments from Brenton, in the Knysna Outlier, Cape Province. Transactions of the Royal Society of South Africa, 40:279-298.

Dingle, R.V. 2009. Implications for high latitude gondwanide palaeozoogeographical studies of someN ew Zealand and A ntarctic Peninsula. Revista Española de M icropaleontología, 41(1/2):145-196.

Fauth, G.; Colin, J-P.; K outsoukos, E.A. \& Bengtson, P. 2005. Cretaceous/Tertiary boundary ostracodes from the Poty Quarry, Pernambuco, northeastern B razil. J ournal of South A merican Earth Sciences, 19(3):285-305.

Fauth, G.; Seeling, J . \& L uther, A . 2003. Campanian (U pper C retaceous) ostracods from southern J ames Ross Island, A ntarctida. Micropaleontology, 49(1):95-107.

Guernet, C. \& Danelian, T. 2006. Ostracodes bathyaux du Cretacé terminal-Éocenemoyen en A tlantiquetropical (Plateau deD emerara, LEG 207). Revue de M icropaléontologie, 49:215-225.

Guernet, C. \& Foucarde, E. 1988. Cenozoic ostracodes from Hole
628 A, ODP L eg 101, B ahamas. P roceedings of the 0 cean D rilling Program, Scientific Results, 101:139-151.

Herrig, E. 1992. N eue Ostrakoden aus verkieselten Kalksteinen der höheren Oberkreide (Ober- $M$ aastricht) der $D$ änisch-Polnischen Furche/O stsee. I. Zeitschrift für G eologische Wissenschaften, 20(1/2):27-49.

Liebau, A. 2005. A revised classification of the higher taxa of the Ostracoda (Crustacea). Hydrobiologia, 538:115-137.

Modica, C.J . \& B rush, E.R. 2004. Postrift sequence stratigraphy, paleogeography, and fill history of the deep water Santos Basin, offshore southeast Brazil. AAPG Bulletin, 88(7):923-945.

M oreira, J.L.P.; M adeira, C.V.; Gil, J .A.\& M achado, M .A .P. 2007. Bacia de Santos. Boletim de Geociências da Petrobras, 15(2):531-549.

Musacchio, E.A. 1979. Datos paleobiogeográficos de algunas asociaciones deforaminíferos, ostrácodosy carófitas del J urásico M edio y el Cretácico Inferior de A rgentina. Ameghiniana, 16:247-271.

M usacchio, E.A. 1981. South A merican J urassic and Cretaceous Foraminifera, Ostracoda and Carophyta of A ndean and Sub-andean regions. In: W. Volkheimer \& E. M usacchio (eds.) Cuencas sedimentarias del J urásico y Cretácico de América del Sur, Comité Sudamericano del J urásico y C retácico, 2:203-224.

M usacchio, E.A . \& Simeoni, M . 2008. Valanginian and Hauterivian marine ostracods from Patagonia (A rgentina): Correlations and palaeogeography. Revue de Micropaléontologie, 51:239-257.

N eale, J.W. 1975. The ostracod fauna from the Santonian Chalk (U pper Cretaceous) of Gingin, Western A ustralia. Special Papers in Palaeontology, 16:1-81.

Nicolaidis, D.D. \& Coimbra, J.C. 2008. Perissocytheridea carrenoae sp. nov. (C rustacea, Ostracoda) and associated calcareous microfauna from Yecua Formation (M iocene), B olivia. Revista Brasileira de Paleontologia, 11(3):179-186.

Pinto, I.D. \& Ornellas, L.P. 1970. A new brackishwater ostracode Perissocytheridea kroemmelbeini Pinto \& Ornellas sp. nov., from southern B razil. Escola de G eologia de P orto Alegre, Publicação Especial, 20:1-19.

Piovesan, E.K., B ergue, C.T.\& Fauth, G. 2009. Cretaceous ostracodes from Pará-M aranhão Basin, Brazil: taxonomy and preliminary paleoecological and paleobiogeographical inferences. Revue de Paléobiologie, 28(2):457-470.

Scotese, C.R. 2009. Cretaceous map. Available at http:// www.scotese.com; accessed on 02/03/2009.

Uliana, M . \& M usacchio, E.A . 1978. M icrofosiles cal cáreos no marinos del Cretácico Superior en El Zampal, Provincia de M endoza, A rgentina. Ameghiniana, 15(1/2):111-135.

Viviers, M.C; K outsoukos, E.A; Silva-Telles J r., A.C. \& Bengtson, P. 2000. Stratigraphy and biogeographic affinities of the lateA ptianCampanian ostracods of the Potiguar and Sergipe basins in northeastern Brazil. Cretaceous Research, 21:407-455.

Whatley, R.C. \& Ballent, S. 1996. A review of the M esozoic ostracod genus Progonocythere and its close allies. Paleontology, 39(4):919-939.

Whatley, R.C. \& Ballent, S. 2004. A review of the M esozoic ostracod genus L ophocythere and its close allies. Paleontology, 47(1):81-108.

Whatley, R.C.; Ballent, S. \& Sczechura, J. 2005. A ntarctic Tertiary Progonocytheridae: the last refuge of $M$ ajungaella, the survivor of a long lineage, a geographical and physiological migration from low to high latitudes. Palaeogeography, Palaeoclimatology, Palaeoecology, 225:302-316.

Whatley, R.C. \& Coles, G. 1987. The L ate M iocene to Quaternary Ostracoda of Leg 94, Deep Sea Drilling Project. Revista Española de Micropaleontología, 19(1):33-97.

Received in M arch, 2010; accepted in August, 2010. 